\title{
EVALUATION OF THE USE OF MALANG SAND AS A FILTER MATERIAL ON WATER QUALITY, PHYSIOLOGICAL RESPONSES AND PRODUCTION PERFORMANCE OF MUD CRAB Scylla serrata
}

\section{EVALUASI PENGGUNAAN PASIR MALANG SEBAGAI BAHAN FILTER TERHADAP KUALITAS AIR, RESPON FISIOLOGI DAN PRODUKSI KEPITING BAKAU Scylla serrata}

\author{
Yuni Puji Hastuti ${ }^{*}$, Arul Tabah Prastomo', Ridwan Affandi², \\ Wildan Nurussalam ${ }^{1}$, Dudi Muhammad Wildan ${ }^{2}$, \& Syamsul Bahri Agus ${ }^{3}$ \\ ${ }^{1}$ Department of Aquaculture, Faculty of Fisheries and Marine Sciences- \\ IPB University, Bogor, 16680, Indonesia \\ ${ }^{2}$ Department of Aquatic Resources Management, Faculty of Fisheries and Marine Sciences- \\ IPB University, Bogor, 16680, Indonesia \\ ${ }^{3}$ Department of Marine Science and Technology, Faculty of Fisheries and Marine Sciences- \\ IPB University, Bogor, 16680, Indonesia \\ *E-mail: yuniha@apps.ipb.ac.id
}

\begin{abstract}
Mud crab Scylla serrata is one of crustacean commodities with high economic value. One of the unsolved obstacles in mud crabs cultivation is crabs' stress level caused by the declining water quality. The recirculating system is a method for maintaining water quality throughout the rearing period of culture crab. This system can use a variety of physical filter materials, such as zeolite, sand, and other materials. This study aimed to determine the amount of malang sand as a physical filter which positively affect the physiological responses and production performance of mud crabs. This research was carried out using a recirculating system with a completely randomized design conducted in five treatments with three replicates, i.e., malang sand with a weight of $0 \mathrm{~kg}$ (control), $5 \mathrm{~kg}, 10 \mathrm{~kg}, 15 \mathrm{~kg}$, and $20 \mathrm{~kg}$. The results proved that the best physiological response and production performance of mud crab was observed at malang sand treatment with a weight of $5 \mathrm{~kg}$. This treatment showed specific growth rate, absolute growth rate for body weight, absolute growth rate for body length, and the survival rate of mud crabs with the highest value of $0.18 \pm 0.061 \%, 0.13 \pm 0.05 \mathrm{~g} / \mathrm{day}, 0.0016 \pm 0.00006 \mathrm{~cm} / \mathrm{day}$, and $77.77 \%$, respectively, yet it had the lowest feed conversion ratio of $3.76 \pm 004$. In addition, the $5 \mathrm{~kg}$ treatment had water quality parameters in the tolerable ranges for mud crabs' growth.
\end{abstract}

Keywords: Malang sand, filter, mud crab, production, recirculation

\section{ABSTRAK}

Kepiting bakau Scylla serrata merupakan salah satu komoditas krustasea yang memiliki nilai ekonomi tinggi. Salah satu kendala yang belum terpecahkan dalam pemeliharaan kepiting bakau adalah tingkat stres kepiting akibat kualitas air yang menurun. Sistem resirkulasi merupakan salah satu cara untuk menjaga kualitas air selama pemeliharaan kepiting budidaya dengan penggunaan air yang sama dan berputar terus menerus melalui filter. Sistem ini dapat menggunakan berbagai material filter fisik, seperti zeolit, pasir dan material lainnya. Penelitian ini bertujuan untuk mengetahui jumlah pasir malang sebagai filter fisik dalam budidaya kepiting bakau yang berpengaruh positif terhadap respons fisiologis dan produksi kepiting bakau. Penelitian ini dilakukan menggunakan sistem resirkulasi dengan rancangan acak lengkap yang dilakukan dalam lima perlakuan dengan tiga ulangan, yaitu pasir malang dengan bobot $0 \mathrm{~kg}$ (kontrol), $5 \mathrm{~kg}, 10 \mathrm{~kg}, 15 \mathrm{~kg}$, dan $20 \mathrm{~kg}$. Hasil penelitian membuktikan bahwa respons fisiologis dan produksi kepiting bakau terbaik diamati pada perlakuan pasir malang dengan bobot $5 \mathrm{~kg}$. Perlakuan ini menunjukkan laju pertumbuhan spesifik, laju pertumbuhan bobot mutlak, laju pertumbuhan panjang mutlak, dan tingkat kelangsungan hidup kepiting bakau dengan nilai tertinggi masing-masing sebesar 0,18 $\pm 0,061 \%, 0,13 \pm 0,05 \mathrm{~g} / \mathrm{hari}, 0,0016 \pm 0,00006 \mathrm{~cm} / \mathrm{hari}$, dan $77,77 \%$, namun memiliki rasio konversi pakan terendah yaitu 3,76 \pm 004 . Selain itu pada perlakuan $5 \mathrm{~kg}$ memiliki nilai kualitas air yang mendekati kontrol.

Kata kunci: filter, kepiting bakau, pasir malang, produksi, resirkulasi 


\section{INTRODUCTION}

Mud crabs (Scylla serrata) are crustaceans inhabiting the coastal waters, namely the border zone between land and sea, especially in mangrove forests. The demand for mud crab in Indonesia continues to increase. Mud crab production in Indonesia remains dominated by natural fishing. The continuous fishing of mud crabs and the decreasing carrying capacity of the natural environment has resulted in a decrease in the population of mud crabs in nature (Monoarfa et al., 2013). To date, the development of mud crab cultivation has not been as good as that of tiger prawns (Penaeus monodon) or vaname shrimp (Litopenaeus vannamei). Throughout the rearing period of mud crab, one of the obstacles faced by farmers is the stress level of the crabs resulted from a decrease in the water quality in aquaculture. Water quality is a factor that greatly influences the physiology of aquatic organisms. Also, water quality is the key to success in the cultivation of crustacean species because it can influence its survival and growth (Pedapoli \& Ramudu, 2014).

The cause of the deterioration of water quality in the cultivation container is the uneaten leftover feed and crab feces which can lead to the accumulation of organic matter. According to Pranoto (2007), this condition is capable of leading to the accumulation of ammonia, nitrite, and nitrate compounds which at certain concentrations are toxic to mud crabs. Declining water quality are able to result in high stress levels, which can cause the inhibition of weight and length growth, and even the death of crabs. Stress is a nonspecific discomfort condition that can result in weakened immunity, reproductive failure, weight loss, and death. The stress level in crabs are able to be observed through the value of total haemocyte count (THC), cholesterol and blood glucose level (Prodjodiharjo, 2002). Basically, the physiological response can be used for monitoring the acute conditions in biota as an early warning (Handy \& Depledge, 1999). Previous methods have been carried out through monitoring the cardiovascular features of beach crabs on closed respiratory conditions and various blood parameters of animals, including hemoglobin, hematocrit, glucose, and other blood proteins.

An innovative way to overcome the constraints of mud crab cultivation is by implementing a recirculating aquaculture system. The recirculating system is a method for maintaining water quality during cultivation by using the same water and rotating continuously through the filter, so the water quality is maintained in acceptable levels for culture biota (Djokosetiyanto et al., 2006). In a recirculating system, filtration is the process of cleaning water by passing it through a porous medium. Physical filters basically apply the principle of filtration. One of the physical filters used in culture containers is malang sand. Not only in the fisheries sector, but many industrial companies have also used sand as a filter material for water treatment. The fishery industry, especially the soft shell crab industry, has used sand as a filter material and water recirculation system in its aquaculture activities (Burden, 1988). The filter has been proven as an effective material for managing water quality and aquaculture production. Sand as a filter material has a surface area of 0.05-0.15 $\mathrm{mm}^{2}$. Apart from being a site for nitrifying and denitrifying bacterial growth, sand is also able to be used as a biological oxygen demand (BOD) reducer in an aquaculture environment. Filter is effective to manage ammonia and nitrite concentration below 1 $\mathrm{ppm}$ and to control the temperature and $\mathrm{pH}$ values in the water.

Sand with optimal size has higher filtration ability on aquaculture waste in order to optimize physical, chemical, and biological water parameters. The growth of potential microbes, such as 
Pseudoalteromonas spongiae, in filter samples which possess a limiting membrane in the form of sand with a size of $0.2 \mu \mathrm{m}$ and a water flow rate of $0.1 \mathrm{~m}^{3} / \mathrm{m}^{2} / \mathrm{h}$ produced a relatively lower abundance of microbes by $3.2 \pm 0.1 \log \mathrm{CFU}$, compared to sand filter with a higher flow rate of $12 \mathrm{~m}^{3} / \mathrm{m}^{2} / \mathrm{h}$ which produce a microbial abundance of up to $3.9 \pm 0.6 \log C F U$ (Oliveira et al., 2019). Sand is not only used as a growing medium for biological parameters, but it also supplies adequate oxygen and supports the biofilm stability of beneficial bacteria. In Indonesia, one of the sand types that is freely sold and is commonly used as filter material is malang sand. Malang sand is resulted from volcano activity and is often referred to as volcanic sand. The effectiveness of sand as a filter material has also been applied to marine worms Polychaeta to manage its aquaculture waste. Sand is utilized as the growth medium for Polychaeta (Perinereis nuntia and $P$. helleri) in the filtration system (Palmer, 2010).

The natural characteristics of malang sand are fine texture and are able to trap particles, such as feces and feed residue, so the feces and feed residue are filtered (Hastuti et al., 2015). A previous study reported the use of varying types of filter materials within the culture container of mud crab under a recirculating system, including zeolith, malang sand, and bioball (Hastuti et al., 2015). However, the most efficient weights of these three filter materials has not been observed. Therefore, the purpose of this present study was to determine the weight of malang sand which results in the best performance of water quality, physiological response, and production of mud crabs.

\section{RESEARCH METHODS}

The rearing of mud crab was conducted at the Laboratory of Aquaculture Environment 2, and analysis of water quality and physiological response of mud crabs were carried out at the Environmental Laboratory 1 and the Laboratory of Aquaculture Environment 2, both are in Department of Aquaculture, Faculty of Fisheries and Marine Sciences, IPB University. While measurement of blood glucose and cholesterol levels was performed at the Laboratory of Animal Physiology, Faculty of Veterinary Medicine, IPB University, Bogor.

\subsection{Research Design}

The experiment was carried out using a completely randomized design, consisting of five treatments with three replications. Treatment was conducted in the form of differences in weight of malang sand, namely without the addition of malang sand (control), addition of $5 \mathrm{~kg}$ of malang sand (5 $\mathrm{kg}$ ), addition of $10 \mathrm{~kg}$ of malang sand (10 $\mathrm{kg}$ ), addition of $15 \mathrm{~kg}$ of malang sand (15 $\mathrm{kg}$ ), and $20 \mathrm{~kg}$ of malang sand $(20 \mathrm{~kg})$. In each treatment, mud crabs were maintained using a recirculation system.

\subsection{The Preparation of Mud Crab Rearing}

The experimental animal used in this study was mud crab (Scylla serrata) using wild-caught seeds obtained from fishermen in Pemalang Regency, Central Java. The crabs were reared in the glass aquarium with a size of $33 \times 50 \times 40 \mathrm{~cm}^{3}$ for five days as the acclimatization period prior to starting the experiment. The number of mud crabs used in this study was 90 individuals with an average weight of $76.86 \pm 14.72 \mathrm{~g}$ and an average carapace width of $7.62 \pm 0.56 \mathrm{~cm}$. The rearing of mud crabs was conducted with a stocking density of six individuals per culture container for 30 days rearing period.

A total of 15 glass aquarium was used in this research as culture container. Each culture container was filled with brackish water made form the mixture of seawater and freshwater. The seawater was obtained from the Ancol area, North Jakarta with a salinity of $35 \mathrm{~g} / \mathrm{L}$, then the seawater 
was stored in the container with a volume of 500 L. Meanwhile, the freshwater was retrieved from the water reservoir in the Department of Aquaculture, Faculty of Fisheries and Marine Science, IPB University, Bogor. The salinity of water used throughout the rearing of mud crabs is $25 \mathrm{~g} / \mathrm{L}$ (Hastuti et al., 2015). Therefore, the seawater was diluted with the addition of freshwater until its salinity reached $25 \mathrm{~g} / \mathrm{L}$ (Hastuti et al., 2015). Water with a salinity of $25 \mathrm{~g} / \mathrm{L}$ was put into each culture container, as well as filter container. The culture container and filter container were filled with water with a capacity of $80 \%$ of the container volume.

\subsection{Feeding Mud Crabs}

The mud crabs were fed with yellow selar fish or ciu fish at a feed rate of $5 \%$ of the biomass (Shelley \& Lovatelli, 2011). The feeding was conducted twice a day at 08.00 and 20.00 western Indonesia time (WIB) using the restricted feeding method.

\subsection{Analysis of Water Quality}

Management of the physical and chemical properties of water quality was carried out using a recirculating system. Water removed from the system was added again according to the initial volume of water with a salinity of $25 \mathrm{~g} / \mathrm{L}$. Measurements of salinity, temperature, $\mathrm{pH}$, and dissolved oxygen (DO) were performed every day, while total ammonia nitrogen (TAN) was measured at the beginning, middle, and end of the rearing period. Water temperature, salinity, DO, $\mathrm{pH}$, and TAN were measured using thermometer, refractometer, DO meter, $\mathrm{pH}$ meter, and spectrophotometer, respectively (Eaton et al., 2005).

\subsection{Physiological and Growth Responses Measurements of Mud Crabs \\ Measurement of the physiological responses, including oxygen consumption}

rate (OCR), total haemocyte count (THC), blood glucose level, and cholesterol levels, were carried out at the beginning and end of cultivation according to Liao \& Huang (1975), Millaty (2014), Wedemeyer \& Yasutake (1977), and Sahu et al. (2005), respectively. The growth performance of mud crabs was determined at the beginning (day 0), middle (day 15), and end (day 30) of 30 days rearing period by measuring the carapace weight and length of three crab samples per replicate. The data were converted to obtain production performance data, such as specific growth rate, feed conversion ratio, absolute growth rate for weight and length body, and survival rate. Specific growth rate and feed conversion ratio were calculated following the formulas described by Zonneveld et al. (1991) and Effendie (1979), respectively. Meanwhile, absolute growth rate and survival rate was measured according to Goddard (1996).

\subsection{Data Analysis}

Data were tabulated and analyzed using Microsoft Excel 2016 and SPSS 24.0. Quantitative descriptive analysis was used to determine the feasibility of the water quality for the growth of mud crabs during this experiment. The data of physiological responses and production performance were examined using the analysis of variance (ANOVA) with a 95\% confidence interval, which was then followed by a LSD test to get the best treatment.

\section{RESULTS}

\subsection{Water Quality during the Rearing Period of Mud Crabs}

The chemical parameters of water quality, such as temperature, DO, salinity and $\mathrm{pH}$, were daily measured during 30 days rearing period of mud crabs (Table 1). Results showed that water temperature, DO, and salinity in all treatments were in the recommended optimal range. Therefore, it can be found that these parameters were not 
Tabel 1. The value ranges of water temperature, DO, salinity, and $\mathrm{pH}$ during 30 days rearing period.

\begin{tabular}{llllllll}
\hline $\begin{array}{l}\text { Water } \\
\text { quality } \\
\text { parameters }\end{array}$ & Control & $5 \mathrm{~kg}$ & $10 \mathrm{~kg}$ & $15 \mathrm{~kg}$ & $20 \mathrm{~kg}$ & $\begin{array}{l}\text { Acceptable } \\
\text { ranges }\end{array}$ & References \\
\hline $\begin{array}{l}\text { Temperature } \\
\left({ }^{\circ} \mathrm{C}\right)\end{array}$ & $\begin{array}{l}26.6- \\
28.0\end{array}$ & $\begin{array}{l}26.7- \\
27.0\end{array}$ & $\begin{array}{l}27.2- \\
27.5\end{array}$ & $\begin{array}{l}27.3- \\
28.0\end{array}$ & $\begin{array}{l}27.8- \\
28.3\end{array}$ & $25-35$ & $\begin{array}{l}\text { FAO } \\
(2011)\end{array}$ \\
$\begin{array}{l}\text { DO (mg/L) } \\
7.1-8.7\end{array}$ & $5.6-6.3$ & $6.0-6,2$ & $6.7-7.0$ & $6.9-7.4$ & $>5$ & $\begin{array}{l}\text { FAO } \\
(2011)\end{array}$ \\
$\begin{array}{l}\text { Salinity } \\
(\mathrm{g} / \mathrm{L})\end{array}$ & 25 & 25 & 25 & 25 & 25 & $10-30$ & $\begin{array}{l}\text { Hastuti et } \\
\text { al. }(2015)\end{array}$ \\
$\mathrm{pH}$ & $7.9-8.7$ & $7.6-7.9$ & $7.4-7.6$ & $6.5-7.1$ & $5.6-6.4$ & $7.0-8.5$ & $\begin{array}{l}\text { Hastuti et } \\
\text { al. }(2016)\end{array}$ \\
\hline
\end{tabular}

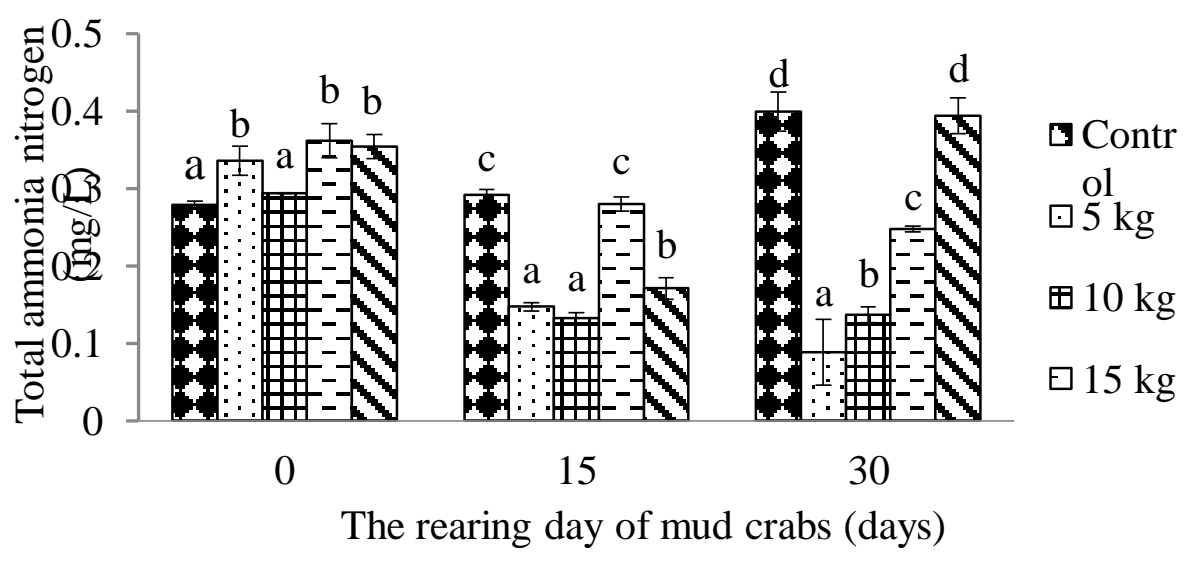

Figure 1. The total ammonia nitrogen (TAN) level $($ Mean \pm SD) in the water throughout the rearing period of mud crabs under malang sand treatments with different weights. Different letters above the bars at the same day denote significant differences among treatments $(P<0.05)$.

affected by the treatments. In contrast, water $\mathrm{pH}$ level had wider ranges in comparison with other parameters.

It was observed that water TAN in 5 $\mathrm{kg}, 10 \mathrm{~kg}$, and $15 \mathrm{~kg}$ malang sand decreased from day 5 to day 30, while TAN in $20 \mathrm{~kg}$ Malang sand decreased on day 15, then increased on day 30 . On the other hand, TAN in the control treatment increased from day 5 to day 30. A low TAN value is an indicator of success in performing filtration. The total ammonia nitrogen in all treatment ranged between $0.08-0.39 \mathrm{mg} / \mathrm{L}$ (Figure 1).

\subsection{Physiological Response of Mud Crabs}

3.2.1. Oxygen Consumption Rate (OCR)

Figure 2 exhibits the oxygen consumption rate of mud crabs on day 1 and day 30 of the rearing period. Results showed that the average OCR of all treatments at the beginning of the rearing period were higher than those at the end of the experiment. Application of $5 \mathrm{~kg}$ malang sand showed a lower OCR compared to other treatments $(P<0.05)$.

Based on Figure 2, it can be found 
that there is a decrease in the value of the level of oxygen consumption. the treatment with the largest decrease was the treatment of $5 \mathrm{~kg}$ malang sand, while the lowest decrease was in the treatment of $15 \mathrm{~kg}$ malang sand. When compared between the 5 $\mathrm{kg}$ malang sand treatment and the control, it can be seen that the use of malang sand has an effect on reducing the level of oxygen consumption.

\subsubsection{Total Haemocyte Count (THC)}

THC of mud crabs at the beginning and end of the cultivation period are presented in Figure 3. Based on Figure 3, on day 1 , the highest average of THC level was observed at $20 \mathrm{~kg}$ malang sand, followed by $10 \mathrm{~kg}, 15 \mathrm{~kg}, 5 \mathrm{~kg}$ malang sand, and control that reached $5.7 \pm 0.10 \times 10^{6}, 4.5 \pm 0.10 \times 10^{6}$, $3.56 \pm 0.15 \times 10^{6}, 3.05 \pm 0.15 \times 10^{6}$, and $2.1 \pm 0.10 \times 10^{6}$ cells $/ \mathrm{mL}$, respectively. THC level from day 1 to day 30 increased under malang sand treatments, while it declined in the control. On day 30, the average of THC level in the descending order were constitutively exhibited by $20 \mathrm{~kg}, 10 \mathrm{~kg}, 15$ $\mathrm{kg}, 5 \mathrm{~kg}$ malang sand, and the control, accounting for $5.7 \pm 0.12 \times 10^{6}, 5.3 \pm 0.10 \mathrm{x}$ $10^{6}, 4.93 \pm 0.10 \times 10^{6}, 4.4 \pm 0.16 \times 10^{6}$, and
$1.8 \pm 0.58 \times 10^{6}$ cells $/ \mathrm{mL}$, respectively.

\subsubsection{Cholesterol Level}

According to Figure 4, the cholesterol level on day 1 from the largest to the smallest number were $10 \mathrm{~kg}$ malang sand $(18.98 \pm 0.01 \mathrm{mg} / \mathrm{dL}), 5 \mathrm{~kg}$ malang sand $(18.30 \pm 0.1 \mathrm{mg} / \mathrm{dL}), 15 \mathrm{~kg}$ malang sand $(12.20 \pm 0.1 \mathrm{mg} / \mathrm{dL}), 20 \mathrm{~kg}$ malang sand $(10.85 \pm 0.1 \mathrm{mg} / \mathrm{dL})$, and control $(4.07 \pm 0.01$ $\mathrm{mg} / \mathrm{dL})$. The cholesterol level on day 30 from the highest to the lowest values were consecutively observed at $10 \mathrm{~kg}$ malang sand $(2.59 \pm 0.08 \mathrm{mg} / \mathrm{dL}), 15 \mathrm{~kg}$ malang sand $(2.15 \pm 0.17 \mathrm{mg} / \mathrm{dL}), 5 \mathrm{~kg}(1.84 \pm 0.06 \mathrm{mg} / \mathrm{dL})$, $20 \mathrm{~kg}$ malang sand $(1.23 \pm 0.04 \mathrm{mg} / \mathrm{dL})$, and control $(0.64 \pm 0.03 \mathrm{mg} / \mathrm{dL})$. The control has a low cholesterol level since first day culture, because the crab is adaptive and there is no effect of treatment from environment.

\subsection{Blood Glucose Level}

Our results showed the similar pattern of blood glucose level in all treatments, which declined from day 1 to day 30 (Figure 5). On day 1, we observed that the mud crabs under $10 \mathrm{~kg}$ malang sands treatment had the highest

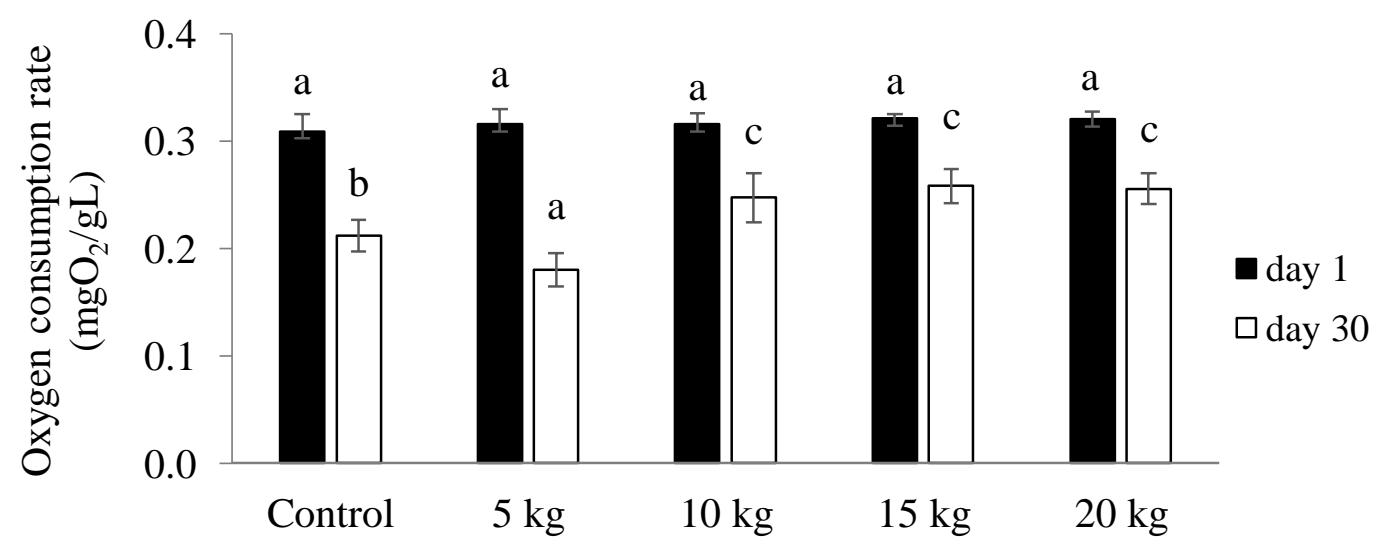

Malang sand treatment with different weights $(\mathrm{kg})$

Figure 2. Oxygen consumption rate (OCR) of mud crabs (Mean \pm SD) at each treatment during the rearing period under different weight of malang sand. Different letters above the bars at the same day denote significant differences among treatments $(P<0.05)$. 


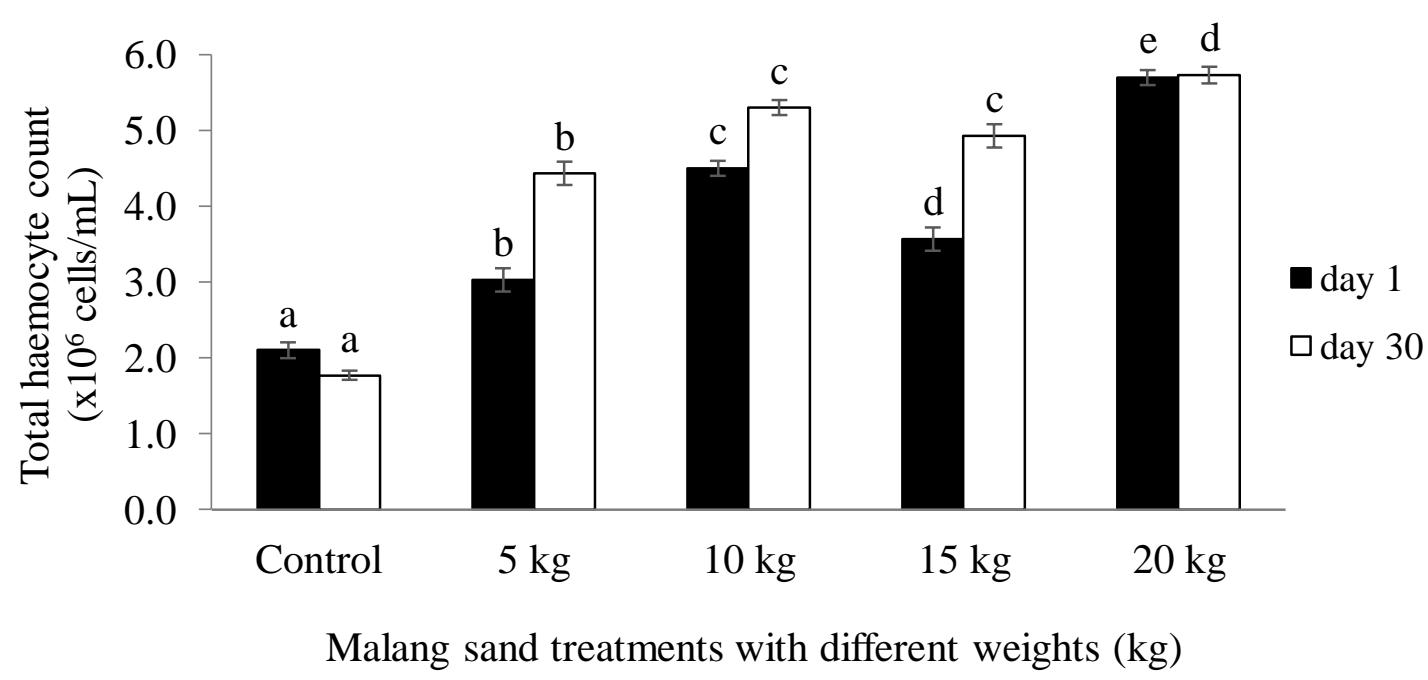

Figure 3. Total haemocyte count (THC) of mud crabs (Mean \pm SD) during the experimental period under different weight of malang sand. Different letters above the bars at the same day denote significant differences among treatments $(P<0.05)$.

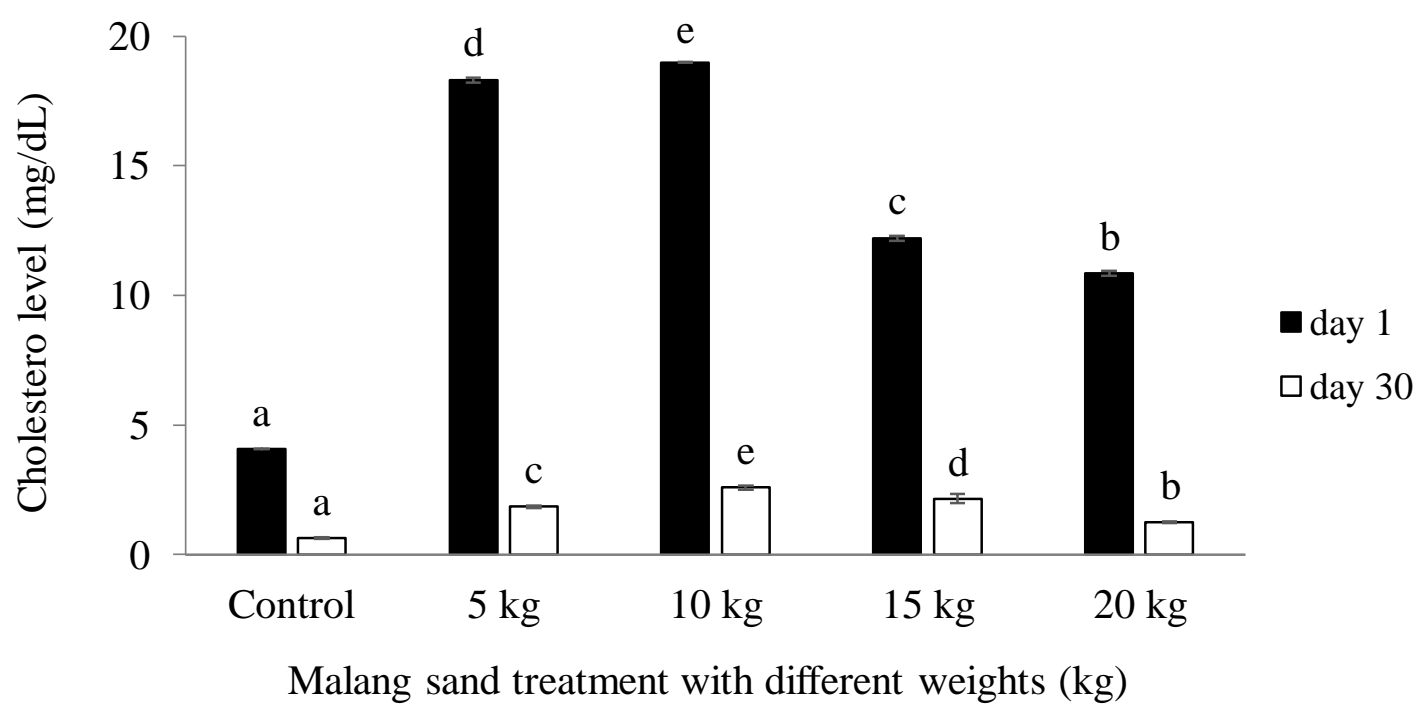

Figure 4. Cholesterol level of mud crabs (Mean \pm SD) at the beginning and end of the rearing period under different weight of malang sand. Different letters above the bars at the same day denote significant differences among treatments $(P<0.05)$.

blood glucose level $(12.98 \pm 0.0 \mathrm{mg} / \mathrm{dL})$, followed by those cultured under $5 \mathrm{~kg}$ malang sand $(12.59 \pm 0.1 \mathrm{mg} / \mathrm{dL}), 15 \mathrm{~kg}$ malang sand $(7.63 \pm 0.1 \mathrm{mg} / \mathrm{dL}), 20 \mathrm{~kg}$ malang sand $(6.87 \pm 0.1 \mathrm{mg} / \mathrm{dL})$, and control $(4.58 \pm 0.0 \mathrm{mg} / \mathrm{dL})$. Meanwhile, on day 30, the blood glucose level of mud crabs from the largest to the smallest value were exhibited by those reared under the control
$(2.62 \pm 0.07 \mathrm{mg} / \mathrm{dL}), 10 \mathrm{~kg}$ malang sand $(1.78 \pm 0.09 \mathrm{mg} / \mathrm{dL}), 15 \mathrm{~kg}$ malang sand $(1.15 \pm 0.17 \mathrm{mg} / \mathrm{dL}), 20 \mathrm{~kg}$ malang sand $(0.95 \pm 0.05 \mathrm{mg} / \mathrm{dL})$, and $5 \mathrm{~kg}$ malang sand $(0.42 \pm 0.12 \mathrm{mg} / \mathrm{dL})$. As the cholesterol level, the control treatment has a low glucose since first day culture, from the start of treatment it had a direct impact to the crabs physiology. 


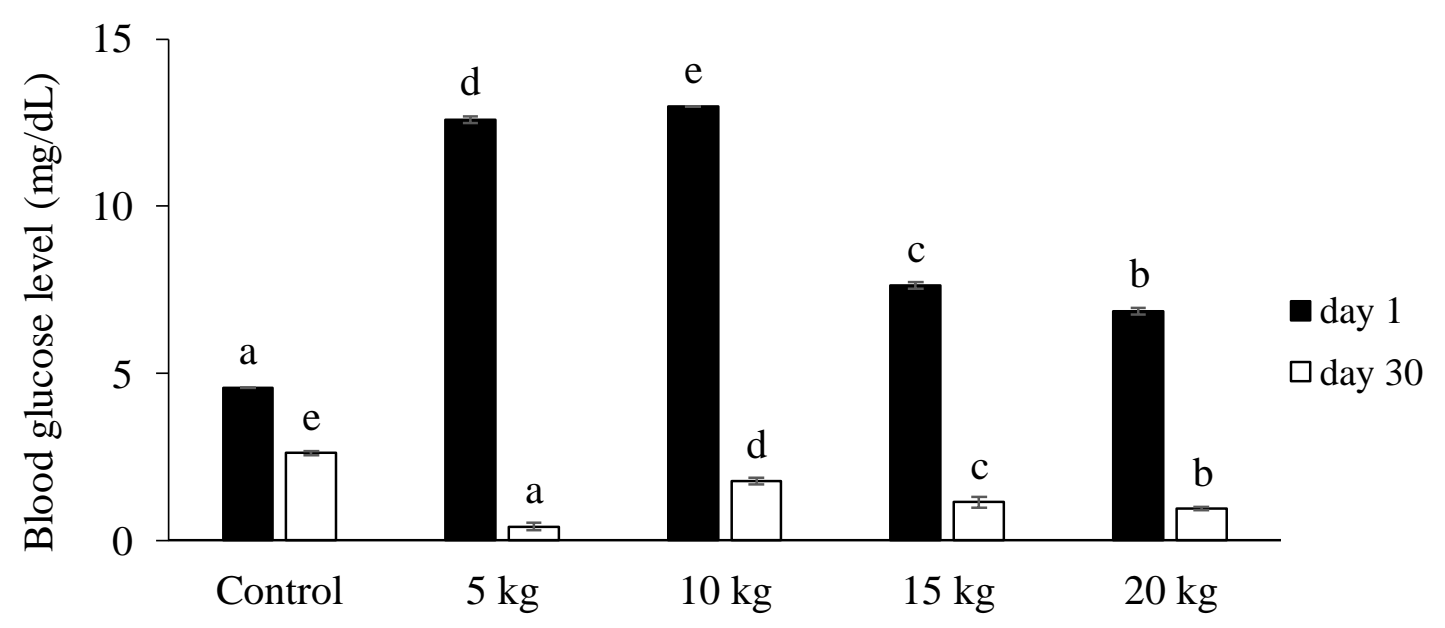

Malang sand treatments with different weights $(\mathrm{kg})$

Figure 5. Blood glucose level of mud crabs $($ Mean \pm SD) at the beginning and end of the rearing period under different weight of malang sand. Different letters above the bars at the same day denote significant differences among treatments $(P<0.05)$.

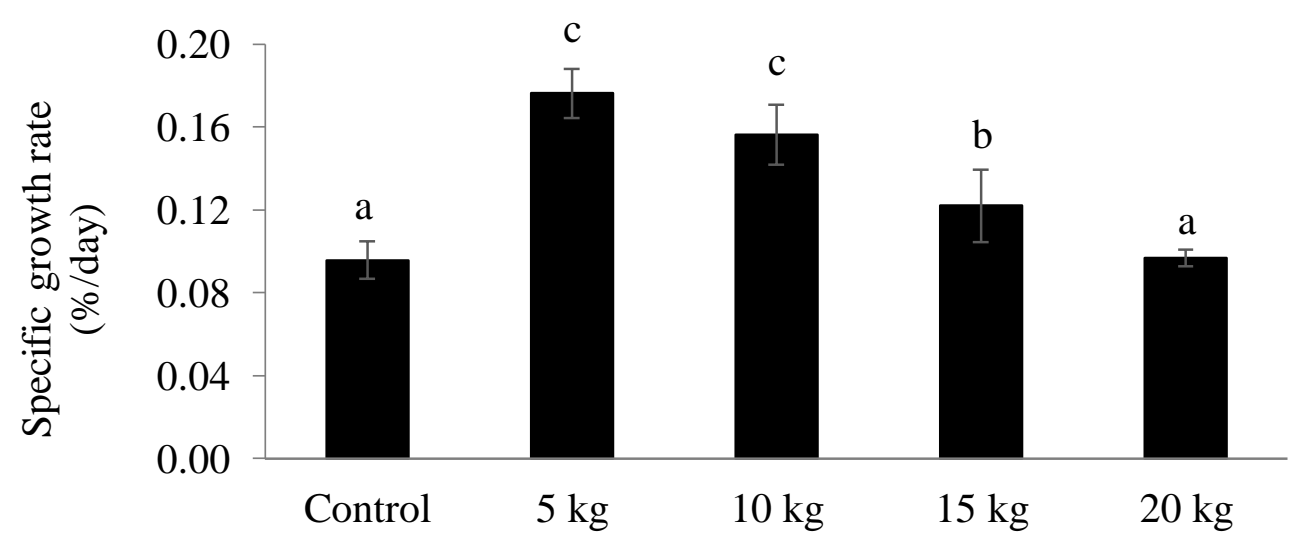

Malang sand treatments with different weights $(\mathrm{kg})$

Figure 6. The specific growth rate of mud crabs $($ Mean \pm SD) reared under different weights of malang sand. Different letters above the bars at the same day denote significant differences among treatments $(\mathrm{P}<0.05)$.

\subsection{Production Performance of Mud Crabs}

\subsubsection{Specific Growth Rate (SGR)}

The specific growth rate (SGR) of mud crab on day 30 are presented in Figure 6. Based on the results obtained, SGR in 5 $\mathrm{kg}$ malang sand treatment had the highest average value of $0.18 \pm 0.061 \%$, followed by $10 \mathrm{~kg}$, control, $20 \mathrm{~kg}$, and $15 \mathrm{~kg}$ with an average value of $0.16 \pm 0.031 \%$, $0.12 \pm 0.054 \%, \quad 0.09 \pm 0.004 \%, \quad$ and $0.09 \pm 0.009 \%$, respectively. This explains that the $5 \mathrm{~kg}$ malang sand treatment has good filtering ability, thereby increasing the growth rate of crabs.

\subsubsection{Feed Consumption Ratio (FCR) \\ FCR with the highest value was}


observed in the control $(4 \pm 0.12 \%)$, while the lowest value was found in $5 \mathrm{~kg}$ malang sand treatment $(3.76 \pm 0.04 \%)$. This results proved that FCR in $5 \mathrm{~kg}$ malang sand treatments was better than in other treatments $(P<0.05)$ (Figure 7).

\subsubsection{Absolute Growth Rate for Body Weight \\ Absolute Growth rate for body}

weight is an indicator of success in crabs culture. data related to absolute growth rate for body weight is presented in Figure 8. Base on Figure 8, the highest absolute growth rate for body weight of mud crabs was in $5 \mathrm{~kg}$ malang sand treatment that achieved $0.13 \pm 0.05 \mathrm{~g} /$ day, followed by 10 $\mathrm{kg}$, control, $15 \mathrm{~kg}$, and $20 \mathrm{~kg}$ with an average value of $0.12 \pm 0.02 \mathrm{~g} / \mathrm{day}, 0.09 \pm 0.04$ g/day, 0.0716 $\pm 0.007 \mathrm{~g} /$ day, and

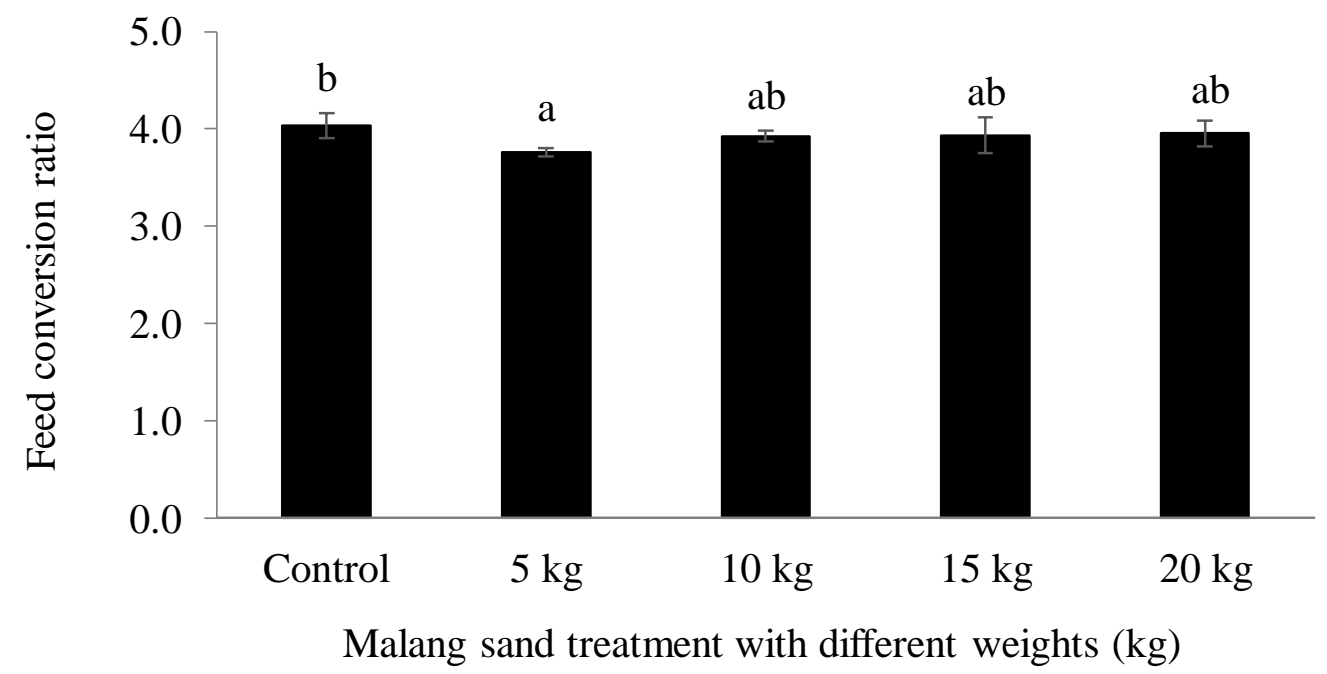

Figure 7. The feed consumption ratio of mud crabs (Mean \pm SD) reared under different weights of malang sand. Different letters above the bars at the same day denote significant differences among treatments $(\mathrm{P}<0.05)$.

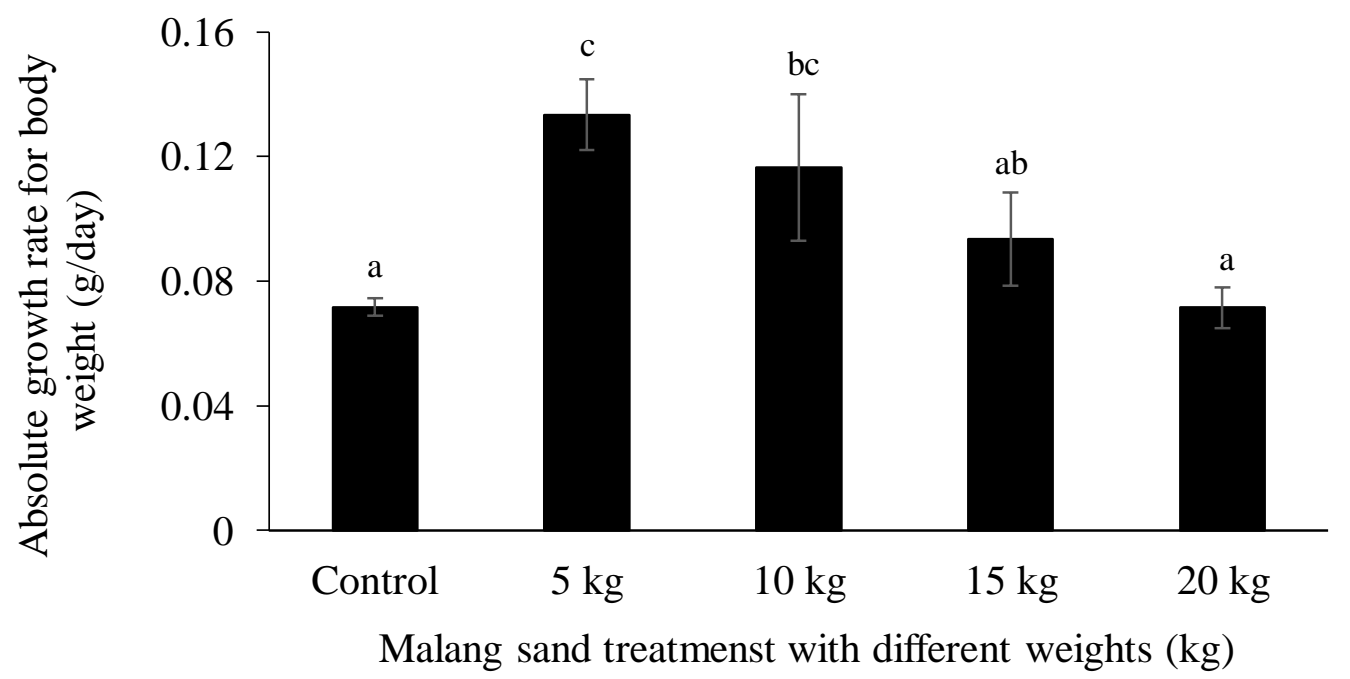

Figure 8. Absolute growth rate for body weight of mud crabs (Mean \pm SD) reared under different weights of malang sand. Different letters above the bars at the same day denote significant differences among treatments $(P<0.05)$. 
$0.0714 \pm 0.002 \mathrm{~g} /$ day, respectively. The highest absolute growth rate value is shown by the malang sand treatment of $5 \mathrm{~kg}$, this explains that, the filter can work well so that the water quality in this treatment most supports the growth of crabs.

\subsubsection{Absolute Growth Rate for Body Length}

The absolute growth rate for body length of mud crabs under $5 \mathrm{~kg}$ malang sand had the highest average value of $0.0016 \pm 0.00006 \mathrm{~cm} /$ day, followed by malang sand treatment with a weight of 10 $\mathrm{kg} \quad(0.0015 \pm 0.0001 \mathrm{~cm} /$ day $), \quad 15 \mathrm{~kg}$ $(0.0009 \pm 0.0003 \quad \mathrm{~cm} /$ day $), \quad 20 \quad \mathrm{~kg}$ $(0.0007 \pm 0.0003 \mathrm{~cm} /$ day $)$, and control $(0.0005 \pm 0.00007 \mathrm{~cm} /$ day) (Figure 9). Based on Figure 9, it was observed that the treatment had a significant effect $(\mathrm{p}<0.05)$ on the absolute growth rate value. Based on these data, it is known that the treatment with the highest absolute growth rate value is the $5 \mathrm{~kg}$ malang sand treatment, while the treatment with the lowest value is the control treatment. Besides that, based on Figure 9, it can be seen that the treatment by adding a filter in the form of malang sand land has a significant effect compared to control. The $5 \mathrm{~kg}$ malang sand treatment is the best treatment in supporting absolute growth rate. This treatment is able to filter well so that it supports the growth of crabs.

\subsubsection{Survival Rate (SR)}

The survival rate of mud crabs for 30 days rearing period under different weights of malang sand ranged from $16.66 \%$ to $77.77 \%$ (Figure 10). The survival rates in the descending order was exhibited by malang sand treatments with a weight of $5 \mathrm{~kg}, 10 \mathrm{~kg}, 15 \mathrm{~kg}, 20 \mathrm{~kg}$, and the control. With the average values of $77.77 \pm 19.245 \%$, $66.66 \pm 16.667 \%$, $61.11 \pm 19.245 \%$, $55.55 \pm 9.623 \%$, and $16.66 \pm 0.000 \%$, respectively.

\section{DISCUSSION}

In mud crabs cultivation conducted in this study, is flowed through a physical filter in the form of malang sand with recirculation system, trapping many particles such as leftover feed and feces so the turbidity or water quality decrease can be minimized. Water quality parameters

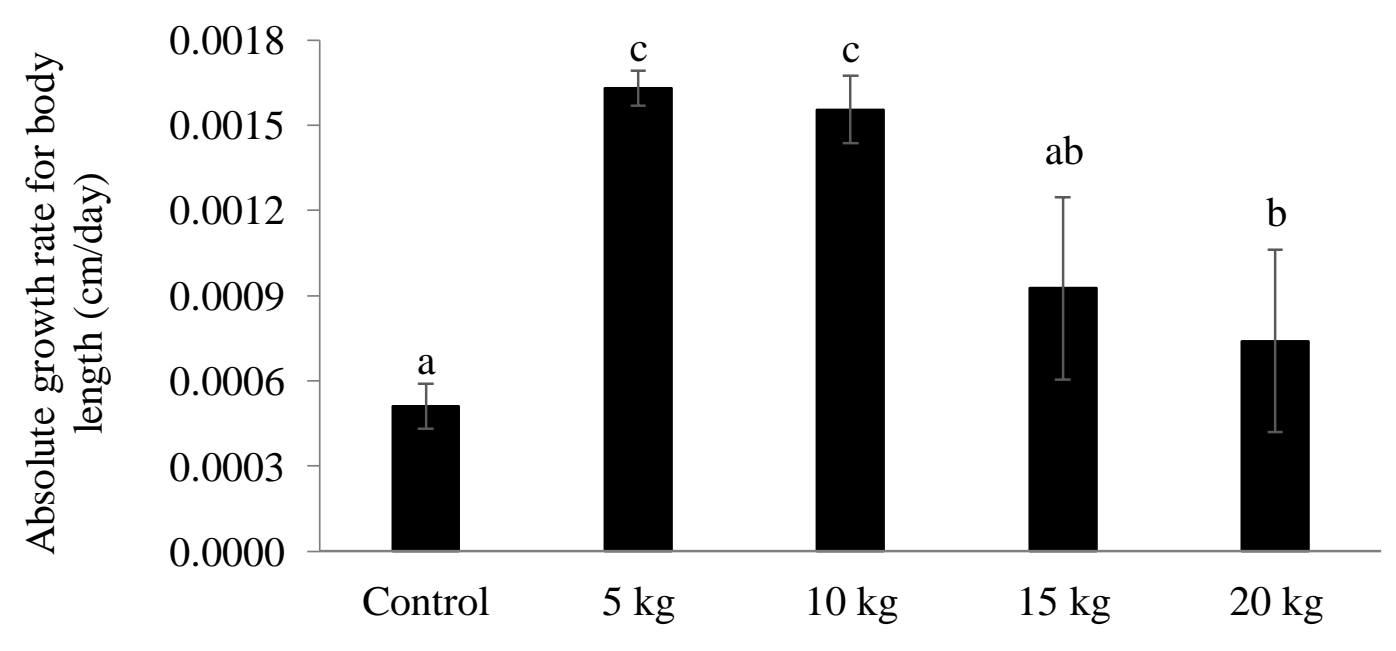

Malang sand treatment with different weights $(\mathrm{kg})$

Figure 9. Absolute growth rate for body length of mud crabs (Mean \pm SD) reared under different weights of Malang sand. Different letters above the bars at the same day denote significant differences among treatments $(P<0.05)$. 


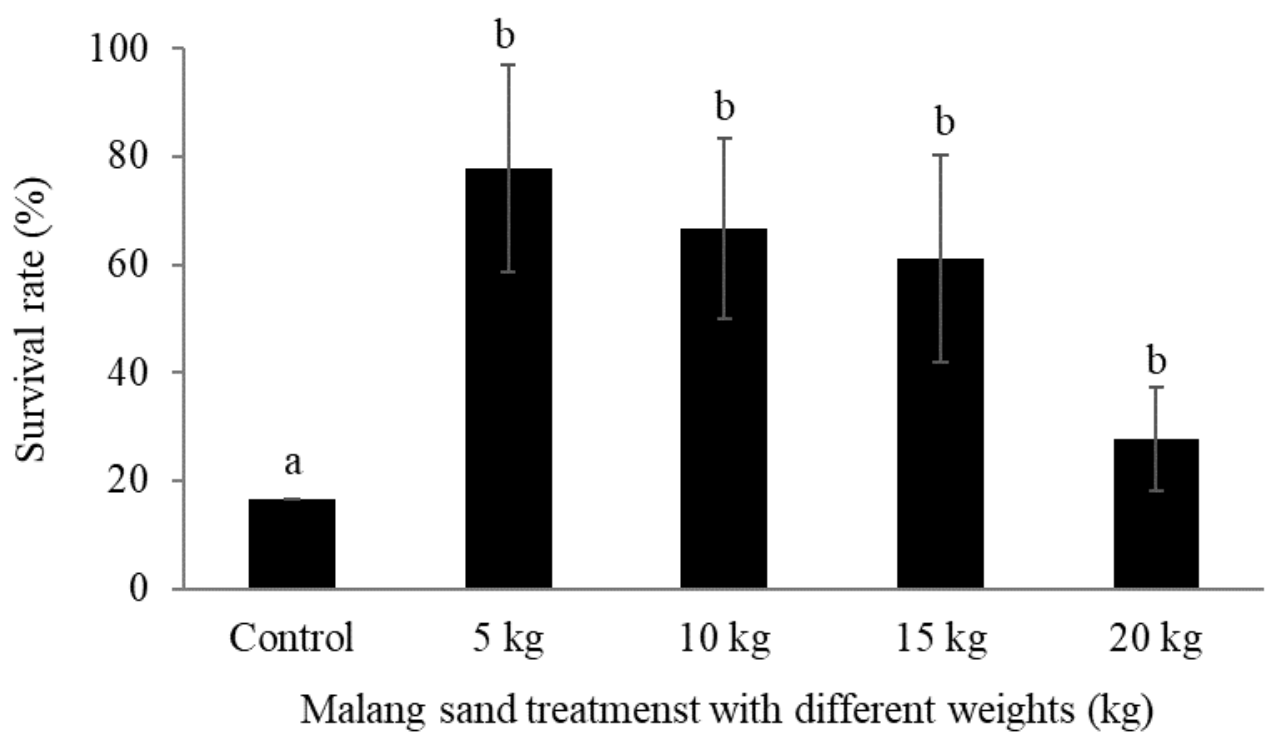

Figure 10. The survival rate of mud crabs $($ Mean \pm SD) on day 30 reared under different weights of Malang sand. Different letters above the bars at the same day denote significant differences among treatments $(P<0.05)$.

observed in this study were temperature, dissolved oxygen (DO), $\mathrm{pH}$, and salinity. The results showed that water temperature, DO, and $\mathrm{pH}$ were in the range of 26.6-28.3 ${ }^{\circ} \mathrm{C}, 5.1-6.5 \mathrm{mg} / \mathrm{L}$, and 5.6-8.7, respectively (Table 1). According to FAO (2011), water quality standards to support crab growth, namely temperature in the range of 25-35 ${ }^{\circ} \mathrm{C}$, DO $>5 \mathrm{mg} / \mathrm{L}, \mathrm{pH}$ in the range of 7.0-8.5, and salinity in the range of 10-30 $\mathrm{g} / \mathrm{L}$. Observed water quality parameters in this study remained at the optimum ranges. This results proved that water temperature, DO and salinity in all treatments were able to support the growth of mud crabs for 30 days rearing period. Apart from the water quality parameters previously mentioned, TAN in the water was also observed in this study. TAN in all treatments ranged between 0.08-0.39 mg/L (Figure 1). Malang sand treatments with a weight of 5,10 , and $15 \mathrm{~kg}$ showed the decreasing TAN level from day 0 to day 30 . TAN in the $20 \mathrm{~kg}$ malang sand treatment declined on day 15 , yet it increased again on day 30. TAN levels in all treatments were considered to be within the optimal ranges set by FAO (2011), i.e., <3 $\mathrm{mg} / \mathrm{L}$. Of all treatments, the highest reduction in TAN levels was observed at the $5 \mathrm{~kg}$ malang sand treatment.

The success of crab rearing activity can be determined through survival rate, growth rate, and feed efficiency. This production performance can be influenced by internal factors and external factors. Internal factors include heredity, age, relative growth rate, sex, resistance to disease, and feed efficiency. External factors comprise water quality, density, and the amount and composition of amino acids or proteins contained in feed (Djunaedi, 2016). The application of malang sand with different weights has proven to be able to support the survival rate of crabs compared to the control. Malang sand with a weight of $5 \mathrm{~kg}$ was able to support the survival rate of crabs by $77.8 \%$. Meanwhile, the specific growth rate, absolute growth rate for body weight and length of mud crabs reared under malang sand treatment with a weight of $5 \mathrm{~kg}$ provided better results compared to other treatments.

Measuring the oxygen consumption rate is a basic way to determine the metabolic rate in fish (Herlinah et al., 2010). Dissolved oxygen plays an important role in 
producing energy through aerobic respiration process. The oxygen consumption rate at the end of the experiment had decreased significantly. The decrease in oxygen consumption rate is able to indicate the lower metabolic activity. This condition relates to the use of a metabolic energy budget, in which the lower the metabolic activity, the less energy will be used for the metabolic process, so it is expected that more energy would be supplied for the growth (Faturrohman, 2017). Our results showed that the oxygen consumption rate with the lowest value was obtained from the $5 \mathrm{~kg}$ malang sand treatment in comparison with other treatments, reached $0.18 \pm 0.015 \mathrm{mgO}_{2} / \mathrm{gL}$ (Figure 2). The $5 \mathrm{~kg}$ malang sand treatment exhibited a lower oxygen consumption rate compared to other treatments $(P<0.05)$ (Figure 2). Low glucose level in the blood is probably due to high energy consumption for the growth of mud crabs. On the other hand, the natural effects of environmental stressors, such as $\mathrm{Cu}$, temperature, hypoxia, and adrenaline on the biochemical response of green crab Carcinus aestuarii is an increase in blood glucose level (Qyli et al., 2020).

Crabs under stress conditions will relocate the metabolic energy from investment activities (growth and reproduction) into homeostasis improvement activities, such as respiration, movement, hydromineral regulation, and tissue repair (Hastuti et al., 2004). Based on the results obtained, the highest glucose level was found at the beginning of the experiment (day 1). The high glucose level at the beginning of the rearing period was caused by the crabs were unable to adapt to the new environment, so the crabs stressed. According to Hastuti et al. (2007), stress causes an increase in blood glucose levels (hyperglycemia). The mechanism of increasing blood glucose levels begins with the process of breaking down liver and muscle glycogen through the glycogenolysis pathway which produces glucose and is an effect of catecholamine metabolism. Then, the breakdown of protein and lipids through the gluconeogenesis pathway is an effect of cortisol metabolism and insulin inactivation resulted from stress hormone metabolism so it inhibits the use of glucose by cells. In our study, the blood glucose levels of mud crabs dropped at the end of the experiment (Figure 5). This decrease indicates that the crabs had been able to adapt to the environment, as previously reported by Hastuti et al. (2016) in crab (Scylla serrata). During the decrease in blood glucose levels, there is an increase in amino acids level in the blood, which is a side process of catabolism. This amino acid will reactivate insulin, so glucose is able to be transported and the glucose level in the blood rises again. Blood glucose levels of mud crabs showed significant different among treatments $(P<0.05)$, in which the application of malang sand with a weight of $5 \mathrm{~kg}$ was the best treatment in reducing the blood glucose levels.

The ability of crabs to respond to disease is greatly influenced by the amount of THC in the crab blood. Haemocytes play an essential role in the crustacean immune system. According to Gunanti et al. (2009), the composition of haemolymph can be measured and can be used as an assessment of crustacean health through the characteristics and activities of the defense system conducted by haemocytes against infectious agents. Haemocytes contribute in phagocytosis, encapsulation, degranulation and nodular aggregation of pathogens or foreign particles. Based on the results obtained, almost all treatments had the increasing THC level from day 0 to day 30 , with the exception of the control. The amount of THC in the control, malang sand treatments with a weight of $5 \mathrm{~kg}, 10 \mathrm{~kg}$, and $15 \mathrm{~kg}$ tended to be low at the initial day of the rearing period. The low THC is probably due to stressed crabs during the acclimatization process. Verghese et al. (2007) reported that environmental changes 
are capable of producing stress on Panulirus homarus lobster. Stress conditions affect the immune response characterized by changes in the amount of THC level, phenoloxidase activity, and phagocytosis activity. Acceptable THC levels for crustaceans are 2-6 $\times 10^{6}$ cells $/ \mathrm{mL}$. In this experiment, all treatments had the THC levels in acceptable ranges, with the exception of the control (Figure 3). Environmental pressure has an effect on reducing THC in green crabs Carcinus aestuarii (Qyli et al., 2020). Cholesterol is a type of lipid which cannot be synthesized by crustaceans directly in their bodies (Kanazawa et al., 1988). The cholesterol levels in the crab body is altered by food availability, age, and environmental factors (Sampaio et al., 2006). The high cholesterol level at the beginning of the rearing period in this study indicates that the mud crab were not able to adapt well to the new environment. Then, the cholesterol levels at the end of the rearing period decreased significantly (Figure 4). Along with increasing maintenance time, $5 \mathrm{~kg}$ sand treatment can support crabs adaptation, seen from an increase of THC and decrease of cholesterol and glucose level. Good adaptation can support of crabs production, one of the parameters is the growth (Figure 9).

Application of $5 \mathrm{~kg}$ malang sand in mud crab cultivation under the recirculation system had the highest specific growth rate $(0.18 \pm 0.061 \%)$ (Figure 6), the lowest feed conversion ratio $(3.76 \pm 0.04 \%)$ (Figure 7 ), the highest absolute growth rate for body weight $(0.13 \pm 0.05 \mathrm{~g} /$ day) (Figure 8$)$, the lowest absolute growth rate for body length $(0.0016 \pm 0.00006 \mathrm{~cm} /$ day) (Figure 9), and the highest survival rate $(77.77 \% \pm 19.245 \%)$ (Figure 10), in comparison with other treatments. Along with the increase in specific growth rate, the body weight of mud crabs also increase during the experimental period. According to the results, malang sand with a weight of $5 \mathrm{~kg}$ in the cultivation of six mud crabs per culture container under the recirculating aquaculture system had the best physiological responses and production performance of mud crabs. The result is observed until the end of the experimental period (day 30), in wich malang sand does not only as physical water filter. The $5 \mathrm{~kg}$ malang sand treatment was able to control the total ammonia in aquaculture environment. It is estimated that sand also acts as a substrate for indigenous nitrifying bacteria (as ammonia oxidizing bacteria). This application would have the potential to be developed in mud crab cultivation with higher density of mud crab under the recirculation system.

\section{CONCLUSION}

Malang sand treatment with a weight of $5 \mathrm{~kg}$ showed the best results compared to other treatments to the physiological responses of mud crabs, such as oxygen consumption rate, total haemocyte count, cholesterol level, and blood glucose levels, and to the production performance of mud crabs, including survival rate, specific growth rate, absolute growth rate, and feed conversion ratio.

\section{ACKNOWLEDGMENT}

The authors gratefully acknowledge the financial support of the Ministry of Research, Technology and Higher Education of the Republic of Indonesia, for grants in the Higher Education Leading Applied Research (PTUPT) program.

\section{REFERENCES}

Burden, G.D. 1988. Development and design of fluidized bed/upflow sand filter configuration for use in recirculating aquaculture systems. Dissertation. Louisiana State University. Louisiana. 140 p.

Food and Agriculture Organization (FAO). 2011. Mud crab aquaculture: a 
practical manual. Food and Agriculture Organization of United Nations. Rome.

Food and Agriculture Organization (FAO). 2013. The state of word fisheries and agriculture. Food and Agriculture Organization of United Nations. Rome.

Ministry of Marine Affairs and Fisheries (KKP). 2015. Jumlah produksi perikanan budidaya tambak menurut jenis ikan dan provinsi 2009-2014. KKP RI. Jakarta.

Djokosetiyanto, D., A. Sunarma, \& Widanarni. 2006. Changes of ammonia, nitrite and nitrate at recirculation system of red tilapia (Oreochromis sp.) rearing. $J$. Akuakultur Indonesia, 5(1): 13-20. https://doi.org/10.19027/jai.5.13-20

Djunaedi, A. 2016. Pertumbuhan dan prosentase molting pada kepiting bakau (Scylla serrata Forsskäl, 1775) dengan pemberian stimulasi molting berbeda. J. Kelautan Tropis, 19(1): 29-36. https://doi.org/10.14710/jkt.v19i1.59 7

Eaton, D.A., Clebceri S.L., Greenberg E.A. 2005. Standard Methods for Examination of Water and Wastewater. 21st edition. Washington DC (US): American Public Health Association.

Effendie, M.I. 1979. Metode biologi perikanan. Yayasan Dewi Sri. Bogor. $112 \mathrm{p}$.

Faturrohman, K. 2017. Determination of optimum dissolved oxygen levels for the growth of mud crab seed Scylla serrata in recirculation systems. Master thesis. Institut Pertanian Bogor. Bogor. $41 \mathrm{p}$.

Goddard, S. 1996. Feed management in intensive aquaculture. Chapman \& Hall. New York. 194 p.

Gunanti, M., Sunarti, J. Triastuti, \& T. Juniastuti. 2009. The destruction and total haemocyte count of tiger shrimp (Penaeus monodon Fab.) that infected Zoothamnium penaei (zoothamniosis). Fisheries and Marine Scientific J., 1(1): 13-14. https://doi.org/10.20473/jipk.v1i1.11 694

Handy, R.D. \& M.H. Depledge. 1999. Physiological responses: their measurement and use as environmental biomarkers in ecotoxicology. Ecotoxicology, 8: 329-49.

https://link.springer.com/article/10.1 023/A:1008930404461

Hastuti, S., E. Supriyono, I. Mokoginta, \& Subandiyono. 2007. Blood glucose response of giant gouramy (Osphronemus gaouramy, Lac.) to the stress of environmental temperature changes. J. Akuakultur Indonesia, 2(2): 73-77. https://doi.org/10.19027/jai.2.73-77

Hastuti, S., I. Mokoginta, D. Dana, \& T. Sutardi. 2004. Stress resistance and immunity response of giant gourami (Osphronemus Gouramy, Lac.) fed on diet containing chromium-yeast. J. Ilmu-Ilmu Perairan dan Perikanan Indonesia, 11(1): 15-21.

Hastuti, Y.P., R. Affandi, M.D. Safrina, K. Faturrohman, \& W Nurussalam. 2015. Optimum salinity for growth of mangrove crab Scylla serrata seed in recirculation systems. J. Akuakultur Indonesia, $\quad$ 14(1): 50-57. https://doi.org/10.19027/jai.14.50-57

Hastuti, Y.P., H. Nadeak, R. Affandi, \& K. Faturrohman. 2016. Optimum pH determination for mangrove crab Scylla serrata growth in controlled containers. J. Akuakultur Indonesia, 15(2): 171-179. https://doi.org/10.19027/jai.15.2.171179

Herlinah, Sulaeman, \& A. Tenriulo. 2010. Pembesaran kepiting bakau (Scylla serrata) di tambak dengan pemberian 
pakan berbeda. Prosiding Forum Inovasi Teknologi Akuakultur 2010: 169-174 pp.

Kanazawa, A., L. Chim, \& L. Laubier. 1988. Tissue uptake of radioactive cholesterol in the prawn Penaeus japonicus Bate during induced ovarian maturation. Aquatic Living Resources, 1(2): 85-91. https://doi.org/10.1051/alr:1988010

Liao, I.C. \& H.J. Huang. 1975. Studies on the respiration of economic prawns in Taiwan, I. Oxygen consumption and lethal dissolved oxygen of egg up to young prawn of Penaeus monodon Fabricius. J. of Fisheries Society of Taiwan, 4 (1): 33-50.

Millaty, R. 2014. Optimum temperature determination for survival rate and growth rate of mud crab Scylla serrata (Forskal) with resirculation system. Undergraduate thesis. Institut Pertanian Bogor. Bogor. 25p.

Monoarfa, S., Syamsuddin, \& S.N. Hamzah. 2013. Analisis parameter dinamika populasi kepiting bakau (Scylla serrata) di Kecamatan Kwandang, Kabupaten Gorontalo Utara. Fisheries and Marine Scientific J., 1(1): 31-36. https://doi.org/10.37905/.v1i1.1214

Oliveira, F.F.D., R.G. Moreira, \& R.P. Schneider. 2019. Evidence of improved water quality and biofilm control by slow sand filters in aquaculture-a case study. Aquaculture Engineering, 85: 80-89. https://doi.org/10.1016/J.AQUAENG .2019.03.003

Qyli, M., V. Aliko, \& C. Faggio. 2020. Physiological and biochemical responses of Mediterranean green crab, Carcinus aestuarii to different environmental stressor: Evaluation of hemocyte toxicity and its possible effects on immune response. Comparative Biochemistry and
Physiology part C: Toxicology and Pharmacology, 231: 108739.

https://doi.org/10.1016/j.cbpc.2020.1 08739

Palmer, P.J. 2010. Polychaeta assisted sand filters. Aquaculture, 306: 369-377. https://doi.org/10.1016/j.aquaculture. 2010.06.011

Pedapoli, S. \& K.R. Ramudu. 2014. Effect of water quality parameters on growth and survivability of mud crab (Scylla tranquebarica) in grow out culture at Kakinada coast, Andhra Pradesh. International J. of Fisheries and Aquatic Studies 2(2): 163-166. https://www.fisheriesjournal.com/vol 2issue2/Pdf/36.1.pdf

Pranoto, S.H. 2007. Isolasi dan seleksi bakteri nitrifikasi dan denitrifikasi sebagai agen bioremediasi pada media pemeliharaan udang vaname (Litopenaeus vannamei). Undergraduate thesis. Institut Pertanian Bogor, Bogor. $64 \mathrm{p}$.

Prodjodiharjo, S. 2002. Pengelolaan daging. Direktorat Jenderal Peternakan Departemen Pertanian. Jakarta.

Sahu, S., R. Chawla R, \& B. Uppai. 2005. Comparison of two methods of estimation of low density lipoprotein cholesterol, the direct versus friedewald estimation. Indian $J$. of Clinical Biochemistry, 20(2): 54-61. https://doi.org/10.1007/BF02867401

Sampaio, G.R., D.H.M. Bastos, R.A.M. Soares, Y.S. Queiroz, \& E.A.F.S. Torres. 2006. Fatty acid and cholesterol oxidation in salted and dried shrimp. Food Chemistry, 95(2): 344-351.

https://doi.org/10.1016/j.foodchem.2 005.02 .030

Shelley C. \& A. Lovatelli. 2011. Mud crab aquaculture "A practical manual". FAO Fisheries and Aquaculture Department. Rome. 100 p.

Verghese, B., E.V. Radhakrishnan, \& A. Padhi. 2007. Effect of environmental 
parameters on immune response of the Indian spiny lobster, Panulirus homarus (Linnaeus, 1758). Fish and Shellfish Immunology, 23(5): 928936.

https://doi.org/10.1016/j.fsi.2007.01. 021

Wedemeyer, G.A. \& I. Yasutake. 1977. Physiology of fish in intensive culture system. Chapman \& Hall. New York. 226 p.
Zonneveld, N., E.A. Huisman, \& J.H. Boon. 1991. Prinsip-prinsip budidaya ikan. PT Gramedia Pustaka Utama. Jakarta. 318 p. significant differences among treatments $(P<0.05)$.

Received : 15 September 2020

Reviewed : 23 November 2020

Accepted : 18 December 2020 